\title{
Michał Raduła
}

Uniwersytet Wrocławski

e-mail: michal.radula@uwr.edu.pl

\section{DZIALALNOŚĆ TELEKOMUNIKACYJNA JEDNOSTEK SAMORZĄDU TERYTORIALNEGO A TELEMEDYCYNA - WYMIAR INSTYTUCJONALNY TELECOMMUNICATION ACTIVITY OF THE LOCAL GOVERNMENT ENTITIES IN RELATION WITH TELEMEDICINE - THE INSTITUTIONAL DIMENSION}

DOI: $10.15611 /$ pn.2017.495.09

Streszczenie: W artykule podjęto problematykę prowadzenia przez jednostki samorzą$\mathrm{du}$ terytorialnego działalności telekomunikacyjnej $\mathrm{w}$ zestawieniu $\mathrm{z}$ regulacjami prawnymi w zakresie udzielania świadczeń zdrowotnych za pośrednictwem systemów teleinformatycznych lub systemów łączności. Postęp technologiczny umożliwia coraz szersze świadczenie różnorodnych usług. Te możliwości aktualizują się także w kontekście świadczeń zdrowotnych, jednakże jeszcze do niedawna, z uwagi na brak odpowiednich regulacji, świadczenie usług na odległość w tym zakresie budziło liczne kontrowersje (autor przedstawia nowelizację przepisów, która zniosła bariery w tej sferze). Publikacja ma także na celu ukazanie kompetencji Prezesa Urzędu Komunikacji Elektronicznej w zakresie kontroli podejmowania i wykonywania przez jednostki samorządu terytorialnego działalności telekomunikacyjnej. Analizie prawnej poddano także usługi telemedyczne, stawiając tezę, że stanowią one usługi o charakterze użyteczności publicznej.

Słowa kluczowe: działalność telekomunikacyjna, telemedycyna, Prezes Urzędu Komunikacji Elektronicznej.

Summary: The article is about telecommunication activity of the local government entities, in relation with legal matters of telemedicine. The technological progress allows providing a different services on a new scale. These possibilities are also actual in the healthcare system context, but in the recent past healthcare services provided at a distance were illegal. The aim of this article is also to describe the competences of the President of the Office of Electronic Communications in the area of control of the local government entities in relation with telecommunication activity. The article also contains the legal analysis of telemedicine, mainly in case if that kind of services can be classified as a public services activity.

Keywords: telecommunication activity, telemedicine, President of the Office of Electronic Communications. 


\section{Pojęcie telemedycyny}

Rozwój technologiczny powoduje informatyzację wszystkich sfer życia społecznego. A zatem, jeśli chodzi o udzielanie świadczeń zdrowotnych, postęp również pozwala na ich usprawnienie, a także szerszy i łatwiejszy dostęp. W odniesieniu do regulacji prawnych należy zauważyć, że prawodawca nie nadąża $z$ normowaniem działalności opartej na nowoczesnych technologiach. Taka sytuacja prowadzi często do luk prawnych, rozbieżności interpretacyjnych, a także do braku możliwości korzystania z dostępnych nowoczesnych rozwiązań z powodów czysto normatywnych (nieuregulowania). W aspekcie normatywnym warto zauważyć, że w obowiązującym kształcie ustawodawstwa brak jest legalnej definicji pojęcia telemedycyny. $\mathrm{Na}$ marginesie należy również zaznaczyć, że do niedawna świadczenie usług zdrowotnych na odległość budziło na tle ówcześnie obowiązujących przepisów prawnych liczne kontrowersje dotyczące dopuszczalności takiej działalności ${ }^{1}$. Ustawą z dnia 9 października 2015 r. o zmianie ustawy o systemie informacji w ochronie zdrowia oraz niektórych innych ustaw ${ }^{2}$ dostosowano regulacje z zakresu ochrony zdrowia, wprowadzając w szczególności możliwość udzielania świadczeń zdrowotnych, a także orzekania o stanie zdrowia za pośrednictwem systemów teleinformatycznych lub systemów łączności.

Definiując zatem zjawisko telemedycyny, odnieść się można do Komunikatu Komisji do Parlamentu Europejskiego, Rady, Europejskiego Komitetu Ekonomiczno-Społecznego oraz Komitetu Regionów w sprawie korzyści telemedycyny dla pacjentów, systemów opieki zdrowotnej i społeczeństwa. Powyższy Komunikat ujmuje pojęcie telemedycyny jako świadczenia zdrowotne udzielane za pomocą technologii informacyjno-komunikacyjnych (Information and Communication Technologies ICT), w sytuacji gdy podmiot, który udziela świadczenia, i pacjent nie znajdują się w tym samym miejscu. „Usługi telemedyczne wiążą się z przesyłaniem danych i informacji medycznych (jako tekstu, obrazu, dźwięku lub w innej formie), które są konieczne do działań prewencyjnych, diagnozy, leczenia i kontroli stanu zdrowia pacjenta"'.

1 Zob. wyrok Wojewódzkiego Sądu Administracyjnego w Warszawie z 10 kwietnia 2015 r., sygn. akt VII SA/Wa 56/15, w którym sąd stwierdził niezgodność z obowiązującymi przepisami prawa udzielania konsultacji lekarskich na odległość.

2 Dz.U. z 2015 r., poz. 1991.

3 Komunikat Komisji do Parlamentu Europejskiego, Rady, Europejskiego Komitetu Ekonomiczno-Społecznego oraz Komitetu Regionów w sprawie korzyści telemedycyny dla pacjentów, systemów opieki zdrowotnej i społeczeństwa, KOM (2008) 689 wersja ostateczna, Bruksela 2008, s. 3; zob. też W. Maczuch, Wybrane etyczne aspekty telemedycyny w świetle standardów konstytucyjnych, Prawo i Medycyna 2005, nr 3 (60, vol. 17), s. 27-52; G. Glanowski, Telemedycyna w świetle ustawy o zawodach lekarza i lekarza dentysty, Monitor Prawniczy 2015, nr 18, Legalis. 


\section{Działalność telekomunikacyjna jednostek samorządu terytorialnego}

Uchwalenie przepisów ustawy o wspieraniu i rozwoju usług i sieci telekomunikacyjnych $^{4}$ (dalej jako: UWRUiST) było częścią przyjętego przez Rząd Rzeczypospolitej Polskiej „Planu stabilności i rozwoju - wzmocnienie gospodarki Polski wobec światowego kryzysu finansowego". Założeniem tej inicjatywy było zintensyfikowanie popytu inwestycyjnego w ramach sektora telekomunikacyjnego. Realizacja zamierzonego celu miała nastąpić poprzez wzmożenie inwestycji w zakresie infrastruktury teleinformatycznej, współfinansowanych ze środków Unii Europejskiej, między innymi poprzez eliminowanie barier natury prawnej. Wyżej wspomniany plan zakładał działania służące zapewnieniu ogólnokrajowego dostępu do szerokopasmowego, światłowodowego Internetu poprzez budowę sieci nowej generacji (NGN Next Generation Network / NGA - Next Generation Access) ${ }^{6}$. W rezultacie umożliwienie użytkownikom końcowym korzystania z Internetu przy większej (wyższej) przepustowości łączy. Cele planu skorelowane były z Programem Operacyjnym Innowacyjna Gospodarka i Programem Operacyjnym Rozwój Polski Wschodniej, które także zakładały zwiększenie inwestycji ze środków pochodzących z Unii Europejskiej w zakresie szerokopasmowych sieci szkieletowych i dostępowych. Bodźcem dla ustanowienia norm w przedmiotowym zakresie była świadomość, że usługi telekomunikacyjne to obecnie podstawowa platforma dostępu i wymiany informacji. Usługi telekomunikacyjne pozwalają na rozpowszechnianie wiedzy, a także świadczenie rozmaitych usług, w swoisty sposób omijając przeszkody geograficzne ${ }^{7}$. Uzasadnienie projektu ustawy podnosi problem niskiego poziomu rozwoju usług telekomunikacyjnych na terytorium RP w stosunku do analogicznych świadczeń w UE. Eksponowano także brak współzależności pomiędzy budową dróg, budynków a jednoczesnym zapewnieniem zaopatrzenia w infrastrukturę teleinformatyczną ${ }^{8}$. Należy również wspomnieć o planach miejscowych, które zbyt często w sposób nieusprawiedliwiony, ustanawiały ograniczenia i wyłączenia w zakresie lokacji infrastruktury przeznaczonej do świadczenie usług telekomuni-

${ }^{4}$ Ustawa z dnia 7 maja 2010 r. o wspieraniu rozwoju usług i sieci telekomunikacyjnych, t.j. z dnia 26 maja 2015 r., Dz.U. z 2015 r., poz. 880 ze zm.

5 Zob. wyrok Wojewódzkiego Sądu Administracyjnego w Warszawie z dnia 17 sierpnia 2011 r., sygn. akt VI SA/WA 943/11.

${ }^{6}$ Zob. więcej P. Gembicki, Regulacja Dostępowych Sieci Nastęnej Generacji (NGA), [w:] M. Rogalski (red.), Prawo telekomunikacyjne, Dom Wydawniczy ABC, Warszawa 2011, s. 227-257.

7 Zob. więcej: Rezolucja Parlamentu Europejskiego z dnia 6 lipca 2011 r. w sprawie internetu szerokopasmowego w Europie: inwestycje na rzecz rozwoju opartego na technologiach szerokopasmowych (2010/2304(INI)); Komunikat Komisji dla Rady, Parlamentu Europejskiego, Europejskiego Komitetu Ekonomiczno-Społecznego i Komitetu Regionów, Niwelowanie różnic w dostępie do łączy szerokopasmowych, Bruksela 2006, KOM (2006) 129 wersja ostateczna.

8 Zob. wyrok Wojewódzkiego Sądu Administracyjnego w Krakowie z dnia 9 stycznia 2014 r., sygn. akt II SA/KR 1226/13. 
kacyjnych. Wreszcie, jako wyrazisty problem, wyszczególniono brak klarownych regulacji w ramach funkcjonowania jednostek samorządu terytorialnego w sektorze telekomunikacyjnym ${ }^{9}$.

Ustawą z dnia 9 czerwca 2016 r. o zmianie ustawy o wspieraniu rozwoju usług i sieci telekomunikacyjnych oraz niektórych innych ustaw ${ }^{10}$ znowelizowano przepisy UWRUiST, dostosowując ich treść do aktualnych realiów społeczno-gospodarczych. Przede wszystkim idzie o implementację do krajowego porządku prawnego dyrektywy Parlamentu Europejskiego i Rady nr 2014/61/UE z dnia 15 maja 2014 r. w sprawie środków mających na celu zmniejszenie kosztów realizacji szybkich sieci łączności elektronicznej ${ }^{11}$. Ponadto potrzeba i cel uchwalenia projektowanej ustawy uzasadniany był koniecznością zapewnienia efektywności Programowi Operacyjnemu Polska Cyfrowa ${ }^{12}$.

Zakres przedmiotowy UWRUiST obejmuje formy i zasady wspierania inwestycji telekomunikacyjnych, w tym również inwestycje w ramach sieci szerokopasmowych $^{13}$. W świetle przepisów ustawy, należy uznać, że jest to główny cel, jaki ma być realizowany za pomoca ustanowionych aktem norm prawnych. Całokształt regulacji sprzyja bowiem przeświadczeniu, że za rozwój usług i sieci telekomunikacyjnych mają odpowiadać w szczególności właściwe formy i zasady wspierania inwestycji. Prawodawca zdecydował się także na uporządkowanie regulacji w obrębie wspomnianego już powyżej problemu - niejasności na płaszczyźnie podejmowania działalności telekomunikacyjnej przez jednostki samorządu terytorialnego. Zatem ustawa normuje także zasady, na jakich jednostki samorządu terytorialnego funkcjonują w sektorze telekomunikacyjnym. Ponadto zakresem ustawowym objęte zostało także uregulowanie w sferze działalności telekomunikacyjnej podmiotów realizujących zadania z zakresu użyteczności publicznej ${ }^{14}$. Ustawa stanowi również

9 Uzasadnienie do projektu ustawy o wspieraniu rozwoju usług i sieci telekomunikacyjnych, http://ww2.senat.pl/k7/dok/sejm/053/2546.pdf, s. 1 i 9-10 (dostęp: 24.05.2016).

${ }^{10}$ Dz.U. z 2016 r., poz. 903.

${ }^{11}$ Dz.Urz. UE L 155 z 23.05.2014, s. 1.

12 Uzasadnienie do projektu ustawy dostępne na orka.sejm.gov.pl (dostęp: 7.07.2016).

${ }^{13} \mathrm{~W}$ rozumieniu ustawy siecią szerokopasmową jest ,sieć telekomunikacyjna służąca do zapewnienia szerokopasmowego dostępu do Internetu. Dostęp określa się jako szerokopasmowy, jeżeli wydajność łącza nie jest czynnikiem ograniczającym możliwość uruchomienia aplikacji dostępnych w sieci" - art. 2 ust. 1 pkt 1 UWRUiST.

${ }^{14}$ Ustawa definiuje podmiot wykonujący zadania z zakresu użyteczności publicznej jako: „podmiot wykonujący zadania z zakresu użyteczności publicznej - osobę fizyczną, osobę prawną lub jednostkę organizacyjną nieposiadającą osobowości prawnej, której przepisy szczególne przyznają zdolność prawną, zapewniającą infrastrukturę techniczną na potrzeby:

a) wytwarzania, przesyłania lub dystrybucji gazu, energii elektrycznej lub ciepła,

b) zapewnienia oświetlenia w miejscach, o których mowa w art. 18 ust. 1 pkt 2 ustawy z dnia 10 kwietnia 1997 r. - Prawo energetyczne, Dz.U. z 2012 r., poz. 1059, z późn. zm.5),

c) zaopatrzenia ludności w wodę, gromadzenia, przesyłania, oczyszczania lub odprowadzania ścieków, ogrzewania, systemów odwodnienia, w tym ciągów drenażowych,

d) transportu, w tym linii kolejowych, dróg, portów i lotnisk;

art. 2 ust. 1 pkt 3 UWRUiST. 
zasady dostępu do infrastruktury telekomunikacyjnej, a także innej infrastruktury technicznej. Ustawodawca zdecydował się ponadto na uregulowanie zasad w zakresie lokalizowania regionalnej sieci szerokopasmowej ${ }^{15}$, a także innej infrastruktury telekomunikacyjnej. Nadto uporządkowaniu prawnemu w drodze ustawy podlegają uprawnienia i obowiązki:

1) inwestorów,

2) właścicieli,

3) użytkowników wieczystych nieruchomości,

4) osób, którym przysługuje spółdzielcze prawo do lokalu,

5) zarządców nieruchomości,

6) lokatorów,

przede wszystkim w ramach dostępu do nieruchomości celem zagwarantowania warunków świadczenia usług telekomunikacyjnych (art. 1 ust. 1 UWRUiST).

Podkreślenia wymaga, że zgodnie z intencją ustawodawcy, omawiana działalność, $\mathrm{tj}$. wspieranie rozwoju usług i sieci telekomunikacyjnych, winno odbywać się z poszanowaniem zasad publicznoprawnej ochrony konkurencji. Wyrazem tego jest stwierdzenie prawodawcy, że „,[p]rzepisy ustawy nie naruszają przepisów o ochronie konkurencji i konsumentów" - tj. przepisów ustawy o ochronie konkurencji i konsumentów ${ }^{16}$ (art. 1 ust. 2 UWRUiST).

Jak już wspomniano, jednym z głównych motywów prawodawcy w ramach stanowienia przepisów UWRUiST była klaryfikacja przepisów w zakresie wykonywania działalności telekomunikacyjnej przez jednostki samorządu terytorialnego. Działania jednostek samorządu terytorialnego, zatem gmin, powiatów i województw, w przedmiotowym zakresie winny być podejmowane celem zaspokajania zbiorowych potrzeb wspólnoty. W ramach powyższej aktywności ustawa wyróżnia następujące obszary:

1) Budowa, eksploatacja, a także nabywanie praw do infrastruktury telekomunikacyjnej i sieci telekomunikacyjnych. Przyjąć przy tym należy, że „eksploatacja” jest terminem rozumianym szeroko - każde korzystanie, zarządzanie infrastrukturą i siecią telekomunikacyjną, natomiast nabywanie praw odnosi się do własności, ograniczonych praw rzeczowych, a także praw obligacyjnych ${ }^{17}$.

${ }^{15}$ Regionalna sieć szerokopasmowa w rozumieniu przepisów ustawy to „sieć szerokopasmowa lub infrastruktura telekomunikacyjna realizowana przez jednostki samorządu terytorialnego, porozumienie, związek lub stowarzyszenie jednostek samorządu terytorialnego, porozumienie komunalne, spółka kapitałowa lub spółdzielnia z udziałem jednostki samorządu terytorialnego, koncesjobiorca w rozumieniu ustawy z dnia 9 stycznia 2009 r. o koncesji na roboty budowlane lub usługi (Dz.U. z 2015 r., poz. 113) albo przez partnera prywatnego w rozumieniu ustawy z dnia 19 grudnia 2008 r. o partnerstwie publiczno-prywatnym (Dz.U. z 2009 r., nr 19, poz. 100, z późn. zm.) w ramach programów operacyjnych - art. 2 ust. 1 pkt 2 UWRUiST.

${ }^{16}$ Ustawa z dnia 16 lutego 2007 r. o ochronie konkurencji i konsumentów, t.j. z dnia 26 stycznia 2015 r., Dz.U. z 2015 r., poz. 184.

${ }^{17}$ Wskazać należy, że zgodnie z art. 2 ust. 2 UWRUiST, ilekroć ustawa posługuje się pojęciami zdefiniowanymi na gruncie ustawy z dnia 16 lipca 2004 r. - Prawo telekomunikacyjne (Dz.U. z 2014 r., 
2) Drugie pole wskazanej działalności obejmuje dostarczanie sieci telekomunikacyjnych, rozumiane jako przygotowanie sieci telekomunikacyjnej w taki sposób, aby za jej pomocą możliwe było świadczenie usług, a także jej eksploatacja i nadzór. Dostarczenie sieci telekomunikacyjnych może także polegać na umożliwianiu dostępu telekomunikacyjnego (art. 2 pkt 4 ustawy - PrTele w zw. z art. 2 ust. 2 UWRUiST). Podkreślenia wymaga także to, że PrTele, obok świadczenia usług telekomunikacyjnych i usług towarzyszących, kwalifikuje jako działalność telekomunikacyjną także dostarczanie sieci telekomunikacyjnych (art. 1 pkt 1 PrTele). W konsekwencji jednostka samorządu terytorialnego, decydując się na podjęcie aktywności w tym zakresie, uzyskuje status przedsiębiorcy telekomunikacyjnego, a wraz z nim nabywa wszelkie uprawnienia i obowiązki przewidziane prawem dla tej kategorii podmiotów ${ }^{18}$.

3) Zapewnianie dostępu do infrastruktury telekomunikacyjnej (do pojedynczych elementów, takich jak np. słupy, kable, przewody, które niekoniecznie muszą być częścią większej całości - sieci telekomunikacyjnej).

4) Świadczenie usług z wykorzystaniem posiadanej infrastruktury telekomunikacyjnej i sieci telekomunikacyjnych na rzecz:

a) przedsiębiorców telekomunikacyjnych,

b) niektórych jednostek i służb administracji rządowej, sił zbrojnych i jednostek organizacyjnych innych państw, a także na rzecz przedstawicielstw dyplomatycznych i innych jednostek o podobnym charakterze (podmioty wskazane w art. 4 pkt 1, 2, 4, 5 i 8 PrTele),

c) użytkowników końcowych, czyli podmiotów, które dla zaspokojenia własnych potrzeb korzystają z publicznie dostępnej usługi telekomunikacyjnej lub które żądają jej świadczenia (w zakresie i na warunkach określonych w art. 6 i 7 UWRUiST).

Działalność jednostek samorządu terytorialnego w powyższym zakresie obwarowana została przez prawodawcę określonymi przesłankami. Przy jej wykonywaniu należy zachować kompatybilność i połączalność z innymi sieciami telekomunikacyjnymi tworzonymi przez podmioty publiczne lub które są finansowane ze

poz. 243, 827 i 1198) (dalej: PrTele), każdorazowo należy je rozumieć w sposób tamże przyjęty. Zatem poprzez infrastrukturę telekomunikacyjną należy rozumieć urządzenia telekomunikacyjne, oprócz telekomunikacyjnych urządzeń końcowych, oraz w szczególności linie, kanalizacje kablowe, słupy, wieże, maszty, kable, przewody oraz osprzęt wykorzystywane do zapewnienia telekomunikacji (art. 2 pkt 8 PrTele w zw. z art. 2 ust. 2 UWRUiST); natomiast przez sieć telekomunikacyjną - systemy transmisyjne oraz urządzenia komutacyjne lub przekierowujące, a także inne zasoby, w tym nieaktywne elementy sieci, które umożliwiają nadawanie, odbiór lub transmisję sygnałów za pomocą przewodów, fal radiowych, optycznych lub innych środków wykorzystujących energię elektromagnetyczną, niezależnie od ich rodzaju (art. 2 pkt 35 PrTele w zw. z art. 2 ust. 2 UWRUiST).

${ }^{18}$ J. Wilczewski, [w:] T. Grossmann et al., Ustawa o wspieraniu rozwoju ustug i sieci telekomunikacyjnych. Komentarz, Warszawa 2013, s. 23. 
środków publicznych ${ }^{19}$. Ponadto aktywność ta winna gwarantować przedsiębiorcom telekomunikacyjnym współkorzystanie i dostęp do infrastruktury i sieci telekomunikacyjnej przy zachowaniu zasady równego traktowania (art. 3 ust. 2 pkt 1 in fine UWRUiST). Przedmiotowa działalność powinna być wykonywana „w sposób przejrzysty i niezakłócający rozwoju równoprawnej i skutecznej konkurencji na rynkach telekomunikacyjnych" (art. 3 ust. 2 pkt 2 UWRUiST).

Ustawodawca zdecydował się na wprowadzenie unormowania stanowiącego o zastosowaniu przepisów o pomocy publicznej w odniesieniu do działalności telekomunikacyjnej jednostek samorządu terytorialnego. Podkreślić należy, że uregulowanie ma na celu raczej komplementarne ukazanie zasad i reguł w obrębie omawianej działalności aniżeli wprowadzenie autonomicznych i swoistych rozwiązań prawnych - prawo pomocy publicznej znajduje zastosowanie w odniesieniu do przedmiotowej działalności, niezależnie od potwierdzenia lub zanegowania ustawowego ${ }^{20}$.

Działalność telekomunikacyjna jednostek samorządu terytorialnego stanowi zadanie własne o charakterze użyteczności publicznej. Interpretacja aktywności jednostek samorządu terytorialnego w tym zakresie winna być zatem skorelowana z przepisami ustawy o gospodarce komunalnej, a także dorobkiem doktryny i orzecznictwa w tej mierze. Zadaniami własnymi jednostki samorządu terytorialnego są zadania publiczne służące zaspokajaniu potrzeb wspólnoty samorządowej (166 KRP). Katalog zadań własnych gminy ma charakter otwarty. Zakres działania gminy obejmuje wszystkie sprawy publiczne o znaczeniu lokalnym, które nie zostały zastrzeżone przepisami rangi ustawowej na rzecz innych podmiotów. Jako przykładowe zostały w nim wyszczególnione także zadania z zakresu ochrony zdrowia oraz zadania w ramach działalności telekomunikacyjnej (wykonywane w imieniu

\footnotetext{
${ }^{19}$ Przez pojęcie środków publicznych należy rozumieć:

1) dochody publiczne;

2) środki pochodzące z budżetu Unii Europejskiej oraz niepodlegające zwrotowi środki z pomocy udzielanej przez państwa członkowskie Europejskiego Porozumienia o Wolnym Handlu (EFTA);

3) środki pochodzące ze źródeł zagranicznych niepodlegające zwrotowi, inne niż wymienione w pkt 2;

4) przychody budżetu państwa i budżetów jednostek samorządu terytorialnego oraz innych jednostek sektora finansów publicznych pochodzące:

a) ze sprzedaży papierów wartościowych,

b) z prywatyzacji majątku Skarbu Państwa oraz majątku jednostek samorządu terytorialnego,

c) ze spłat pożyczek i kredytów udzielonych ze środków publicznych,

d) z otrzymanych pożyczek i kredytów,

e) z innych operacji finansowych;

5) przychody jednostek sektora finansów publicznych pochodzące z prowadzonej przez nie działalności oraz pochodzące z innych źródeł (art. 3 ust. 2 pkt 1 UWRUiST w zw. z art. 5 ust. 1 ustawy z dnia 27 sierpnia 2009 r. o finansach publicznych, Dz.U. z 2013 r., poz. 885 ze zm.).

${ }^{20} \mathrm{O}$ pomocy publicznej zob. więcej w: C. Kosikowski, Publiczne prawo gospodarcze Polski i Unii Europejskiej, Lexis Nexis, Warszawa 2010, s. 167-176; K. Strzyczkowski, Prawo gospodarcze publiczne, Lexis Nexis, Warszawa 2011, s. 475-515.
} 
własnym i na własną odpowiedzialność $)^{21}$. Zadaniami samorządu powiatowego są zadania publiczne o charakterze ponadgminnym, w tym zadania z obszaru promocji i ochrony zdrowia, a także w zakresie działalności telekomunikacyjnej ${ }^{22}$. Analogicznie gdy idzie o zadania samorządu województwa - stanowią one zadania publiczne o charakterze wojewódzkim, które nie zostały zastrzeżone ustawą na rzecz organów administracji rządowej, a obejmują swym zakresem między innymi promocję i ochronę zdrowia oraz działalność w zakresie telekomunikacji ${ }^{23}$. Należy przy tym wyraźnie zaznaczyć, że nie należy utożsamiać zadań własnych jednostek samorządu terytorialnego z zadaniami o charakterze użyteczności publicznej. Zadania własne w większości będą kwalifikowane jako zadania o charakterze użyteczności publicznej, jednakże katalog zadań własnych jednostek samorządu terytorialnego zawiera również zadania, które pozbawione są cech użyteczności publicznej ${ }^{24}$.

Mając na uwadze powyższe, działalność jednostki samorządu terytorialnego jako podmiotu powołanego celem urzeczywistniania dobra wspólnego ${ }^{25}$ i interesu publicznego ${ }^{26}$ nie cechuje się dowolnością, lecz prawnym związaniem w postaci obowiązku wykonywania zadań publicznych. Ponadto prawodawca, ustanawiając,

${ }^{21}$ Art. 7 ust. 1 pkt 3a i 5 w zw. z art. 2 ust. 1 ustawy z dnia 8 marca 1990 r. o samorządzie gminnym, t.j. z dnia 17 marca 2016 r., Dz.U. z 2016 r., poz. 446.

${ }^{22}$ Art. 4 ust. 1 pkt 2 i 23 ustawy z dnia 5 czerwca 1998 r. o samorządzie powiatowym, t.j. z dnia 19 maja 2016 r., Dz.U. z 2016 r., poz. 814.

${ }^{23}$ Art. 14 ust. 1 pkt 2 i 15 a ustawy z dnia 5 czerwca 1998 r. o samorządzie województwa, t.j. z dnia 1 kwietnia 2016 r., Dz.U. z 2016 r., poz. 486.

${ }^{24}$ W. Gonet, Ustawa o gospodarce komunalnej, Lexis Nexis, Warszawa 2010, s. 15; zob. też C. Banasiński, M. Kulesza, Ustawa o gospodarce komunalnej, Dom Wydawniczy ABC, Warszawa 2002, s. 11-30; M. Bałdyga, Gospodarka komunalna - aspekty prawne, Alpha Pro, Ostrołęka 2004, s. 27-33; K. Byjoch, S. Redeł, Prawo gospodarki komunalnej, Wydawnictwo Naukowe PWN, Warszawa 2000, s. 55-66; B. Rakoczy, Prawo gospodarki komunalnej, Wydawnictwo Naukowe PWN, Warszawa 2010, s. 12-13; S. Dudzik, Działalność gospodarcza samorzadu terytorialnego. Problematyka prawna, Zakamycze, Kraków 1998, s. 253-312.

${ }^{25}$ O pojęciu „dobra wspólnego” zob. więcej w: C. Znamierowski, Szkoła prawa. Rozważania o państwie, Oficyna Naukowa, Warszawa 1988, s. 76-80; M. Piechowiak, Dobro wspólne jako fundament polskiego porządku konstytucyjnego, Biuro Trybunału Konstytucyjnego, Warszawa 2012, s. 38; K. Complak, Normy pierwszego rozdziału Konstytucji RP, Wydawnictwo Uniwersytetu Wrocławskiego, Wrocław 2007, s. 49; H. Izdebski, M. Kulesza Administracja publiczna. Zagadnienia ogólne, Wydawnictwo Liber, Warszawa 2004, s. 96; A. Pakuła, Bezpieczeństwo publiczne jako dobro wspólne (kilka uwag i refleksji), [w:] A. Chajbowicz, T. Kocowski (red.), Bezpieczeństwo wewnętrzne w dziataniach terenowej administracji publicznej, Kolonia Limited, Wrocław 2009, s. 29 - 35.

${ }^{26} \mathrm{O}$ instytucji interesu publicznego zob. szerzej w: W. Jakimowicz, Wyktadnia w prawie administracyjnym, Zakamycze, Kraków 2006, s. 116; J. Langrod, Instytucja prawa administracyjnego. Zarys cześsi ogólnej, Zakamycze, Kraków 2003, s. 41; o różnorodności treści interesu publicznego zob. Z. Cieślak, [w:] Z. Niewiadomski (red.), Prawo administracyjne, Lexis Nexis, Warszawa 2011, s. 56; Z. Niewiadomski, [w:] Z. Duniewska et al., Instytucje prawa administracyjnego, seria: System Prawa Administracyjnego, R. Hauser, Z. Niewiadomski, A. Wróbel (red.), Wydawnictwo C.H. Beck, Warszawa 2015, s. 15; zob. też P.J. Suwaj, Konflikt interesów w administracji publicznej, Wolters Kluwer Polska, Warszawa 2009, s. 42-43; J. Łętowski, Prawo administracyjne. Zagadnienia podstawowe, Państwowe Wydawnictwo Naukowe, Warszawa 1990, s. 15; J. Zimmermann, Prawo administracyjne, 
że działalność telekomunikacyjna prowadzona przez jednostki samorządu terytorialnego utożsamia zadanie własne o charakterze użyteczności publicznej, wskazał, iż winna ona być zdeterminowana dążeniem do bieżącego i nieprzerwanego zaspokajania zbiorowych potrzeb ludności w drodze świadczenia usług powszechnie dostępnych (działalność o charakterze użyteczności publicznej). Wszelką zatem aktywność jednostek samorządu terytorialnego w przedmiotowym zakresie, która nie posiadałaby wspomnianych powyżej cech (determinant zadań o charakterze użyteczności publicznej), należy uznać za niedopuszczalną (z wyjątkiem tworzenia przez województwo spółek z ograniczoną odpowiedzialnością i spółek akcyjnych, jeżeli prowadzą one działalność telekomunikacyjną służącą rozwojowi województwa $)^{27}$.

\section{Kompetencje Prezesa Urzędu Komunikacji Elektronicznej w odniesieniu do dzialalności telekomunikacyjnej jednostek samorządu terytorialnego}

Prezes UKE jest centralnym organem administracji rządowej, powoływanym i odwoływanym na pięcioletnią kadencję przez Sejm za zgodą Senatu na wniosek Prezesa Rady Ministrów. Pełni funkcję organu regulacyjnego w dziedzinie rynku usług telekomunikacyjnych i pocztowych. Do zakresu działania organu należy przede wszystkim: realizacja zadań w obrębie regulacji i kontroli rynków usług telekomunikacyjnych, analiza i ocena funkcjonowania tych rynków (także pocztowych), gospodarka w obszarze zasobów częstotliwości, zasobów numeracji, prowadzenie rejestru przedsiębiorców telekomunikacyjnych, a także wykonywanie zadań ustanowionych przez UWRUiST ${ }^{28}$.

Wolters Kluwer Polska, Warszawa 2014, s. 26; J. Starościak, Prawo administracyjne, Wydawnictwo Naukowe PWN, Warszawa 1977, s. 12.

${ }^{27}$ M. Szydło, [w:] T. Grossmann et al., op. cit., s. 57-59.

${ }^{28}$ Warto na marginesie zaznaczyć, że art. 199 ust. 1 PrTele stanowi, że „Prezes UKE jest uprawniony do kontroli przestrzegania przepisów”, wydaję się jednak, iż w kontekście organu administracji publicznej właściwe byłoby posłużenie się terminem „kompetencji”, zatem swoistej administracyjnoprawnej wiązki obowiązku i uprawnienia - zob. więcej: R. Michalska-Badziak, [w:] M. Stahl (red.), Prawo administracyjne. Pojęcia, instytucje, zasady w teorii i orzecznictwie, Dom Wydawniczy ABC, Warszawa 2013, s. 268; M. Matczak, Kompetencja organu administracji publicznej, Zakamycze, Kraków 2004, s. 32-36; S. Wąsowicz, Stosunki prawne, [w:] A. Łopatka et al., Zarys teorii państwa i prawa, Wydawnictwo Naukowe Uniwersytetu im. Adama Mickiewicza w Poznaniu, Poznań 1963, s. 397; T. Rabska, Podstawowe pojęcia organizacji administracji, [w:] J. Starościak (red.), System prawa administracyjnego, tom I, Ossolineum, Wrocław 1977, s. 325; T. Rabska, Przedsiębiorstwo państwowe jako podmiot administracji gospodarczej, Państwowe Wydawnictwo Naukowe, Poznań 1966, s. 111; T. Rabska, Prawo administracyjne stosunków gospodarczych, Wydawnictwo Naukowe PWN, Warszawa - Poznań 1977, s. 55; T. Rabska, Prawny mechanizm kierowania gospodarka, Zakład Narodowy im. Ossolińskich, Wrocław - Warszawa - Kraków 1990, s. 109 i 125; A. Chełmoński, Instytucje administracyjnoprawne w zarzadzaniu gospodarka narodowa, [w:] T. Rabska (red.), System prawa administracyjnego, tom IV, Ossolineum, Wrocław - Warszawa - Kraków - Gdańsk 1980, s. 438. 
Na mocy art. 4 ust. 1 UWRUiST jednostki samorządu terytorialnego zyskały uprawnienie do wystąpienia z wnioskiem do Prezesa Urzędu Komunikacji Elektronicznej (dalej: Prezes UKE) o wydanie opinii w sprawie wykonywania działalności telekomunikacyjnej. Wniosek składany jest przed podjęciem działalności i powinien zawierać projekt planu z uwzględnieniem formy, rodzaju i zakresu planowanej działalności, a także opisu sytuacji na obszarze działalności telekomunikacyjnej. Wniosek podlega opłacie, która stanowi dochód budżetu państwa, a jej wysokość określa w drodze rozporządzenia minister właściwy do spraw łączności po zasięgnięciu opinii Prezesa UKE ${ }^{29}$. Opłata nie może przewyższać kwoty 5000 zł i winna być zależna od rodzaju i rozmiaru planowanej działalności. Ustawa przewiduje, że w przedmiotowym wniosku powinny znaleźć się informacje dotyczące liczby mieszkańców na danym obszarze, stopnia pokrycia zasięgiem sieci telekomunikacyjnych wraz z podziałem na rodzaje tych sieci. Ponadto wnioskujący podmiot zamieszcza obligatoryjnie we wniosku wiadomości dotyczące odsetka mieszkańców, którzy na danym obszarze korzystają z usług telekomunikacyjnych, liczby przedsiębiorców telekomunikacyjnych (na wskazanym obszarze) wraz z opisem zakresu ich działalności (telekomunikacyjnej), a także wszystkie inne informacje, które stanowią istotny element $\mathrm{w}$ ocenie zapotrzebowania na podjęcie przez jednostkę samorządu terytorialnego działalności telekomunikacyjnej. Wniosek powinien być rozpatrzony przez Prezesa UKE - w formie wydania opinii - w terminie 3 miesięcy od dnia jego otrzymania.

Powyższe rozwiązanie należy niewątpliwie uznać za trafne, albowiem swoiste uprzywilejowanie jednostek samorządu terytorialnego w zakresie opiniowania przez Prezesa UKE spełniania wymogów wykonywania działalności telekomunikacyjnej (świadczenie usług na odpowiednim poziomie, kwestie związane z ochroną konkurencji na rynku), jak się wydaje, ma swoje źródło w istocie podejmowania tych działań - zaspokajania zbiorowych potrzeb wspólnoty. Jednostki samorządu terytorialnego dotychczas niezaangażowane w działalność telekomunikacyjną uzyskują na mocy ustawy uprawnienie do zaopiniowania planowanej działalności pod względem zgodności z obowiązującymi regulacjami. Należy jednak podkreślić, że przedmiotowa opinia nie ma charakteru wiążącego i w żaden sposób nie stanowi przeszkody ku późniejszemu stwierdzeniu przez Prezesa UKE, że określona działalność jest prowadzona niezgodnie z ustawą ${ }^{30}$. Oprócz opinii co do legalności planowanej aktywności, przedmiotowa opinia może pomóc wnioskującemu podmiotowi w podjęciu decyzji co do efektywności zaplanowanej efektywności i wprowadzenia ewentualnych korekt ${ }^{31}$.

${ }^{29}$ Rozporządzenie Ministra Infrastruktury z dnia 25 czerwca 2010 r. w sprawie wysokości opłaty za wniosek o opinię Prezesa Urzędu Komunikacji Elektronicznej dotyczącą wykonywania przez jednostkę samorządu terytorialnego działalności w zakresie telekomunikacji (Dz.U. z 2010 r., nr 118, poz. 796).

${ }^{30}$ J. Wilczewski, op. cit., s. 63-64.

${ }^{31}$ Uzasadnienie do projektu ustawy o wspieraniu rozwoju usług i sieci telekomunikacyjnych, http://ww2.senat.pl/k7/dok/sejm/053/2546.pdf, s. 18 (dostęp: 24.05.2016). 
Prezes UKE w odniesieniu do działalności telekomunikacyjnej jednostek samorządu terytorialnego jest organem nadzorczym, w przypadku bowiem stwierdzenia, że działalność jest wykonywana niezgodnie z wymaganiami, o których była mowa powyżej, może podjąć decyzję o:

1) nakazaniu usunięcia stwierdzonych nieprawidłowości,

2) wskazaniu środków, którymi należy się posłużyć, aby usunąć nieprawidłowości,

3) określeniu dopuszczalnego zakresu i warunków, na jakich świadczone będą usługi telekomunikacyjne na rzecz użytkowników końcowych,

4) wskazaniu terminu, do którego nastąpić ma usunięcie nieprawidłowości lub dostosowanie działalności do zakresu i warunków świadczenia usług telekomunikacyjnych użytkownikom końcowym (art. 77 ust. 3 pkt 1-3 UWRUiST).

Decyzja Prezesa UKE powinna uwzględniać interes użytkowników końcowych, uzasadniony interes wspólnoty samorządowej, warunki, jakie muszą spełnić jednostki samorządu terytorialnego, aby móc wykonywać działalność telekomunikacyjną. Ponadto Prezes UKE, podejmując decyzję w omawianym zakresie, winien mieć na względzie środki, które należy podjąć celem usunięcia nieprawidłowości, a także że ,dopuszczalny zakres i warunki świadczenia usług telekomunikacyjnych użytkownikom końcowym nie mogą uniemożliwiać wykonywania dotychczasowej działalności" (art. 77 ust. 3 in fine UWRUiST).

Niezależnie od powyższego, nowelizacja przepisów PrTele z dnia 26 listopada 2012 r. $^{32}$, spowodowała objęcie jednostek samorządu terytorialnego wykonujących działalność telekomunikacyjną kontrolą na gruncie przepisów ustawy - Prawo telekomunikacyjne. W konsekwencji Prezes UKE może wydać tym podmiotom zalecenia pokontrolne, jeżeli nie stosują się one do obowiązków ustawowych lub mających swe źródło w treści decyzji Prezesa UKE. Treść wezwania zawartego w zaleceniu pokontrolnym może przybrać formę wezwania do usunięcia nieprawidłowości lub udzielenia wyjaśnień (w terminie wskazanym przez Prezesa UKE), jednakże nie może być on krótszy niż 30 dni od dnia doręczenia zaleceń podmiotowi kontrolowanemu, chyba że naruszenia wskazane w zalecaniach powtarzały się w przeszłości lub podmiot kontrolowany wyraził zgodę na skrócenie terminu (art. 201 ust. 1 in fine i ust. 2 PrTele). Po upływie powyższego terminu, wyznaczonego celem usunięcia wskazanych nieprawidłowości lub udzielenia wyjaśnień, jeżeli podmiot kontrolowany nie usunie tych nieprawidłowości lub udzieli wyjaśnień w sposób niewystarczający, Prezes UKE wydaje decyzję nakazującą usunięcie stwierdzonych nieprawidłowości. Ponadto Prezes UKE może wskazać środki, które powinien podjąć podmiot kontrolowany, niezbędne, aby usunąć nieprawidłowości, a także termin do ich usunięcia. Oprócz powyższego Prezes UKE może na podmiot kontrolowany nałożyć karę pieniężną (art. 201 ust. 3 pkt 3 w zw. z art. 209 PrTele). Od wydanej

${ }^{32}$ Art. 1 pkt 13 ustawy z dnia 16 listopada 2012 r. o zmianie ustawy - Prawo telekomunikacyjne oraz niektórych innych ustaw, Dz.U. z 2012 r., poz. 1445. 
decyzji podmiotowi kontrolowanemu przysługuje odwołanie do Sądu Okręgowego w Warszawie - Sądu Ochrony Konkurencji i Konsumentów (art. 206 ust. 2 PrTele) ${ }^{33}$.

Warto również zaznaczyć, że w przypadku gdy podmiot kontrolowany nie zastosuje się do powyższej decyzji, a ujawnione w toku kontroli nieprawidłowości miały już miejsce w poprzednio prowadzonych postępowaniach kontrolnych, a także gdy uchybienia mają poważny charakter, Prezes UKE może wydać decyzję dotyczącą zakazu prowadzenia działalności telekomunikacyjnej. Decyzji zakazującej prowadzenia działalności nadaje się rygor natychmiastowej wykonalności, jest ona również aktem administracyjnym, na podstawie którego możliwe jest wykreślenie podmiotu kontrolowanego z właściwego rejestru (rejestru jednostek samorządu terytorialnego wykonujących działalność w zakresie telekomunikacji niebędącej działalnością gospodarczą) prowadzonego przez Prezesa UKE - art. 10 ust. la PrTele lub jeśli działalność jednostek samorządu terytorialnego nosi znamiona działalności telekomunikacyjnej, będącej działalnością gospodarczą, z rejestru przedsiębiorców telekomunikacyjnych - art. 10 ust. 1 PrTele $^{34}$.

\section{Podsumowanie}

Na gruncie powyższych rozważań należy potwierdzić tezę, że działalność telekomunikacyjna jednostek samorządu terytorialnego, wespół z powołaną nowelą przepisów umożliwiającą wykonywanie świadczeń zdrowotnych za pośrednictwem systemów teleinformatycznych lub systemów łączności, umożliwia w najbliższej przyszłości upowszechnienie usług telemedycznych. Warto również zaznaczyć wyjątkowe uprawnienie jednostek samorządu terytorialnego do wystąpienia do Prezesa UKE z wnioskiem o opinię w sprawie wykonywanej działalności. Takie rozwiązanie $\mathrm{z}$ pewnością niweluje ryzyko wykonywania przez jednostki samorządu terytorialnego działalności telekomunikacyjnej niezgodnej z przepisami, a tym samym może spowodować większe zainteresowanie samorządów omawianą działalnością. Warto również gwoli podsumowania wymiaru instytucjonalnego rozpatrywanej problematyki wspomnieć o konieczności podjęcia przez organ stanowiący jednostki samorządu terytorialnego uprzedniej uchwały legalizującej podjęcie działalności telekomunikacyjnej. Ponadto informacja o podjęciu przez jednostkę samorządu terytorialnego działalności z zakresu telekomunikacji winna zostać ogłoszona w Biuletynie Informacji Publicznej zamieszczonym na stronie internetowej danej jednostki, a także w jej siedzibie. Co więcej, informacja o zainicjowaniu aktywności w tym zakresie przekazywana jest Prezesowi UKE, który niezwłocznie informuje o podjętej działalności na stronie internetowej Urzędu Komunikacji Elektronicznej.

${ }^{33}$ Zob. szerzej: S. Piątek, Prawo telekomunikacyjne. Komentarz, Wydawnictwo C.H. Beck, Warszawa 2013, s. 1190-1200.

${ }^{34}$ Zob. więcej: A. Krasuski, Prawo telekomunikacyjne. Komentarz, Dom Wydawniczy ABC, Warszawa 2015, s. 1575-1578. 


\section{Literatura}

Bałdyga M., 2004, Gospodarka komunalna - aspekty prawne, Alpha Pro, Ostrołęka.

Banasiński C., Kulesza M., 2002, Ustawa o gospodarce komunalnej, Dom Wydawniczy ABC, Warszawa.

Byjoch K., Redeł S., 2002, Prawo gospodarki komunalnej, Wydawnictwo Naukowe PWN, Warszawa.

Chajbowicz A., Kocowski T. (red.), 2009, Bezpieczeństwo wewnętrzne w działaniach terenowej administracji publicznej, Kolonia Limited, Wrocław.

Complak K., 2007, Normy pierwszego rozdziału Konstytucji RP, Wydawnictwo Uniwersytetu Wrocławskiego, Wrocław.

Dudzik S., 1998, Działalność gospodarcza samorządu terytorialnego. Problematyka prawna, Zakamycze, Kraków.

Duniewska Z. et al., 2015, Instytucje prawa administracyjnego, seria: System Prawa Administracyjnego, R. Hauser, Z. Niewiadomski, A. Wróbel (red.), Wydawnictwo C.H. Beck, Warszawa.

Glanowski G., 2015, Telemedycyna w świetle ustawy o zawodach lekarza i lekarza dentysty, Monitor Prawniczy nr 18, Legalis.

Gonet W., 2010, Ustawa o gospodarce komunalnej, Lexis Nexis, Warszawa.

Grossmann T., Knopkiewicz W., Sebzda-Załuska J., Szydło M., Wilczewski J., 2013, Ustawa o wspieraniu rozwoju ustug i sieci telekomunikacyjnych. Komentarz, Wydawnictwo C.H. Beck, Warszawa.

Izdebski H., Kulesza M., 2004, Administracja publiczna. Zagadnienia ogólne, Wydawnictwo Liber, Warszawa.

Jakimowicz W., 2006, Wyktadnia w prawie administracyjnym, Zakamycze, Kraków.

Kosikowski C., 2010, Publiczne prawo gospodarcze Polski i Unii Europejskiej, Lexis Nexis, Warszawa.

Krasuski A., 2015, Prawo telekomunikacyjne. Komentarz, Dom Wydawniczy ABC, Warszawa.

Langrod J., 2003, Instytucja prawa administracyjnego. Zarys części ogólnej, Zakamycze, Kraków.

Łętowski J., 1990, Prawo administracyjne. Zagadnienia podstawowe, Państwowe Wydawnictwo Naukowe, Warszawa.

Łopatka A., Nowaczyk J., Wąsowicz S., Wojtkowiak D., Ziembiński Z., 1963, Zarys teorii państwa i prawa, Wydawnictwo Naukowe Uniwersytetu im. Adama Mickiewicza w Poznaniu, Poznań.

Maczuch W., 2005, Wybrane etyczne aspekty telemedycyny w świetle standardów konstytucyjnych, Prawo i Medycyna, $\mathrm{nr} 3$ (60, vol. 17).

Matczak M., 2004, Kompetencja organu administracji publicznej, Zakamycze, Kraków.

Niewiadomski Z. (red.), 2011, Prawo administracyjne, Lexis Nexis, Warszawa.

Piątek S., 2013, Prawo telekomunikacyjne. Komentarz, Wydawnictwo C.H. Beck, Warszawa.

Piechowiak M., 2012, Dobro wspólne jako fundament polskiego porządku konstytucyjnego, Biuro Trybunału Konstytucyjnego, Warszawa.

Rabska T., 1966, Przedsiębiorstwo państwowe jako podmiot administracji gospodarczej, Państwowe Wydawnictwo Naukowe, Poznań.

Rabska T., 1977, Prawo administracyjne stosunków gospodarczych, Wydawnictwo Naukowe PWN, Warszawa - Poznań.

Rabska T., 1990, Prawny mechanizm kierowania gospodarka, Zakład Narodowy im. Ossolińskich, Wrocław - Warszawa - Kraków.

Rabska T. (red.), 1980, System prawa administracyjnego, tom IV, Ossolineum, Wrocław - Warszawa - Kraków - Gdańsk.

Rakoczy B., 2010, Prawo gospodarki komunalnej, Wydawnictwo Naukowe PWN, Warszawa.

Rogalski M. (red.), 2011, Prawo telekomunikacyjne, Dom Wydawniczy ABC, Warszawa.

Stahl M. (red.), 2013, Prawo administracyjne. Pojęcia, instytucje, zasady w teorii i orzecznictwie, Dom Wydawniczy ABC, Warszawa. 
Starościak J., 1977, Prawo administracyjne, Wydawnictwo Naukowe PWN, Warszawa. Starościak J. (red.), 1977, System prawa administracyjnego, tom I, Ossolineum, Wrocław. Strzyczkowski K., 2011, Prawo gospodarcze publiczne, Lexis Nexis, Warszawa.

Suwaj P.J., 2009, Konflikt interesów w administracji publicznej, Wolters Kluwer Polska, Warszawa.

Zimmermann J., 2014, Prawo administracyjne, Wolters Kluwer Polska, Warszawa.

Znamierowski C., 1988, Szkoła prawa. Rozważania o państwie, Oficyna Naukowa, Warszawa. 